ppi $201502 Z U 4645$

Esta publicación científica en formato digital es continuidad de la revista impresa ISSN-Versión Impresa 0798-1406 / ISSN-Versión on line 2542-3185Depósito legal pp $197402 Z$ U34
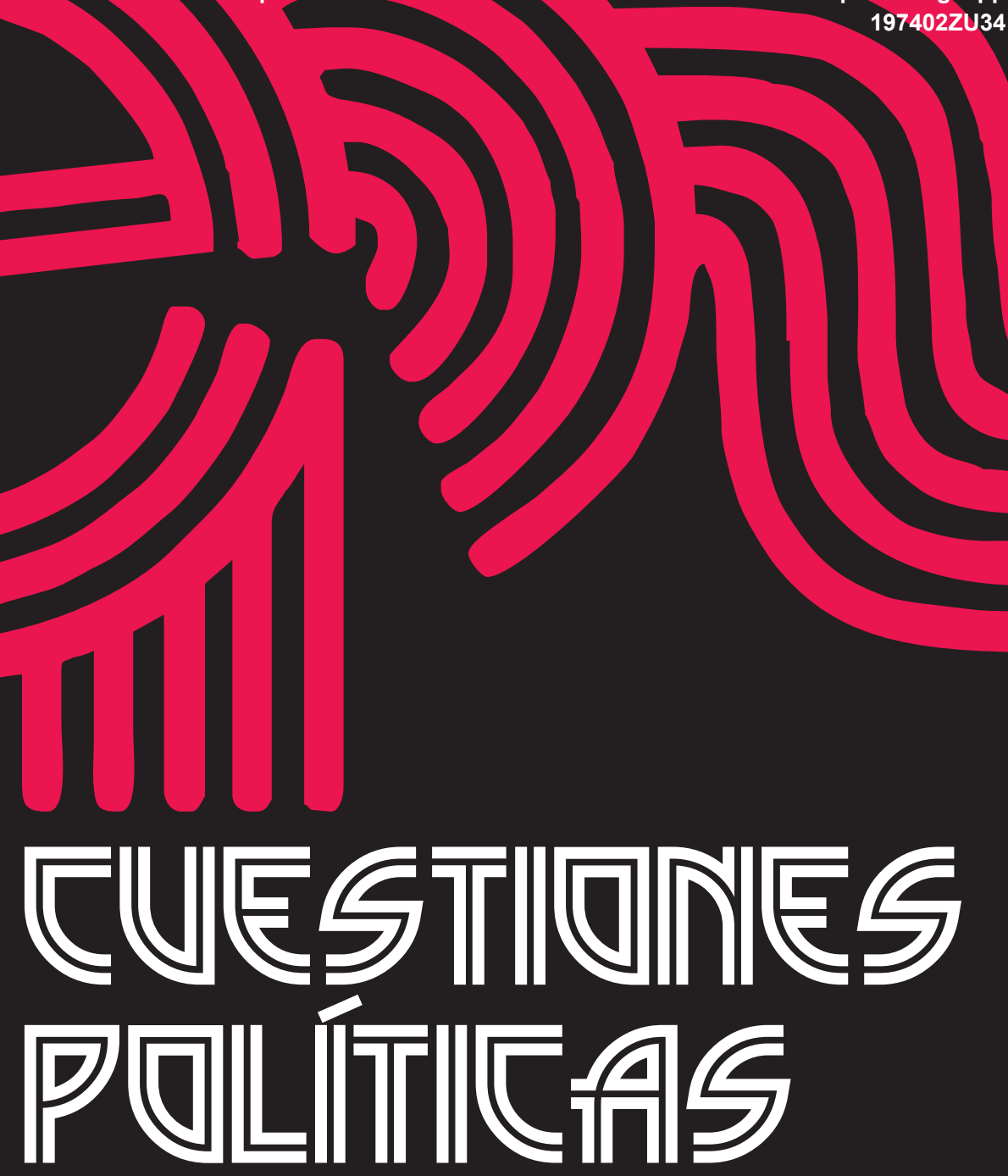

Instituto de Estudios Políticos y Derecho Público "Dr. Humberto J. La Roche" de la Facultad de Ciencias Jurídicas y Políticas de la Universidad del Zulia Maracaibo, Venezuela
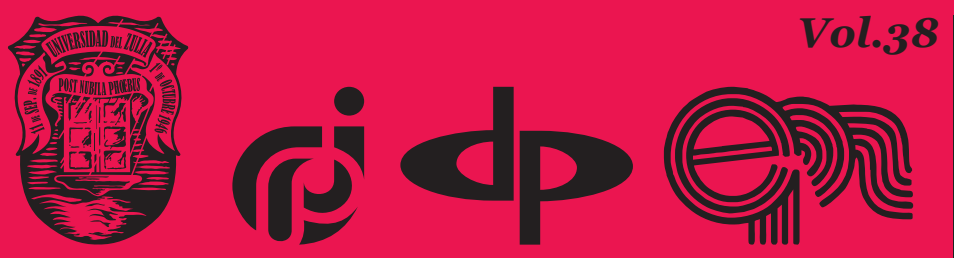

$N^{\circ}$ Especial 2da Parte 2020 


\title{
The philosophy of private deterrence in the penal code
}

\author{
DOI: https://doi.org/10.46398/cuestpol.382e.10
}

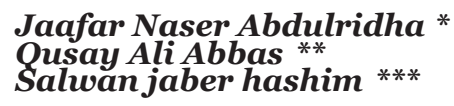

\begin{abstract}
The aim of article was to discuss the philosophy of private deterrence under Iraq's penal code. The methodology adopted was the inductive approach, which helps to extrapolate legal texts with this study and the jurisprudence of legal jurists. The Legislator applies to the threat with punishment the harm and pain that will be inflicted on them if the crime is eaten by law, what is known as public deterrence speech. For its part, the special deterrent will be responsible for reforming the meaning and morality of the offender, following various means provided by the legislature and desinging a method of education of the deprived of liberty, allowing them the voluntary work determined by the conditions of each penance conditions or even by the subsequent formal and informal reintegration mechanisms of exconvictions. It is concluded that these methods and others can contribute significantly to the achievement of the deterrence objectives, which is to reform and evaluate the offender's conduct according to criminal gravity on
\end{abstract} a case-by-case basis.

Keywords: philosophy private deterrence; general deterrence; penal code; Iraqi legislation; preventive measures of crime.

Senior Lecturer, Kazan Federal University, (Faculty of law), Al-Basrah University Republic of Iraq, (Constitutional and administrative law). ORCID ID: http://orcid.org/oooo-ooo2-7154-1176. Email: Jaafarna124@mail.ru

** Republic of Iraq, Baghdad, Al-Nahrain University, Faculty of Law /Al Nahrain University. Iraq (Criminal Law), ORCID ID: http://orcid.org/oooo-0oo2-9332-7728. Email: qusay688954@gmail. com

*** Senior Lecturer /Faculty of Law /Al Nahrain University. Iraq (International law). ORCID ID: http:// orcid.org/oooo-0oo2-4235-2157. Email: sellwan@mail.ru 


\section{La filosofía de la disuasión privada en el código penal de Irak}

\section{Resumen}

El objetivo de articulo fue discutir la filosofía de la disuasión privada en el marco del código penal de Irak. La metodología adoptada fue el enfoque inductivo, que ayuda a extrapolar los textos legales relacionados con este estudio y las opiniones jurisprudenciales de juristas de derecho. El Legislador busca imponer y comunicar un castigo a la conducta delictiva, lo que se conoce como el discurso disuasivo privado y también pretende informar a las personas amenazando con castigar el daño y dolor que se les infligirá si cometieron el delito penalizado por la ley, lo que se conoce como discurso de disuasión pública. Por su parte, el disuasivo especial se ocupa de reformar el comportamiento y la moral del delincuente, siguiendo varios medios proporcionados por el legislador e ideando un método de educación de los privados de libertad, permitiéndoles el trabajo voluntario determinado por las condiciones de cada institución penitenciaria o incluso por los posteriores mecanismos de reinserción formal e informal de los exconvictos. Se concluye que, estos métodos y otros pueden contribuir significativamente al logro de los objetivos de disuasión, que es reformar y evaluar la conducta del delincuente según la gravedad delictiva inherente a la profundidad de cada caso.

Palabras clave: filosofía disuasión privada; disuasión general; código penal; legislación iraquí; medidas preventivas del delito.

\section{Introduction}

The importance of this research lies in explaining the role of private deterrence, which is one of the objectives of the punishment in reforming and correcting the behavior of the perpetrators, as private deterrence cannot be the goals that were set for it unless there are a number of methods to be followed in reforming the perpetrators, the most important of which is the commitment of the reform institution to teach and refine the perpetrators. And health care and other things that may lead to the convicts feeling regret and regret for the crime or crimes they have committed.

The research problem arises in the statement defining the concept of private deterrence, as this concept is still vague and different doctrinal, as the research problem emerges in defining the philosophical basis for private deterrence and the extent to which this deterrence is affected by the newly introduced penalties such as electronic surveillance and the system 
of pledging honor which are not stipulated in some legislations, including Iraqi legislation.

\section{Methods}

The methodology that we will adopt is the inductive approach, which helps us in extrapolating the legal texts related to this study and the jurisprudential opinions of jurists of law related to this topic.

\section{Results}

One of the most important manifestations of private deterrence that the relevant authorities must implement is the inclusion of the convict in his educational courses, which is the obligation to teach and cultivate, as well as to pay attention to the convict's health care.

Education of the convict and refining it: private deterrence achieves the educational and educational function. Education as well as education are among the most important means that contribute to acquiring social values and raising the intellectual and moral level of the prison. Education also plays an important role in reducing the percentage of crime in society and eliminating illiteracy, which is one of the contributing factors. On the appearance of criminality and its spread in society, it inspires confidence in the psychology of the prisoner through the knowledge he acquires from education (Mekki, 2010).

Most of the penal institutions in the prison administration work to provide teachers and professional trainers who are able to provide the detainees with all the knowledge, as they frame educational facilities with all appropriate means and equipment, and most of the penal institutions prepare scientific plans to develop the educational and educational capabilities of the convicted inmates (Al-Taher, 2009).

Also, giving lectures and lessons on prisons will be according to the educational level of inmates, and according to programs usually prepared through the Ministry of Justice in each country, in addition to distributing books, newspapers, and magazines. These books and newspapers contribute to the entertainment and entertainment of prisoners, and enter in the field of education and education, obtaining Religious and moral information, in order to develop good and virtue in the same inmate, which affects the inmate's beliefs, behavior and behavior, and then transform the perpetrator into an ordinary person and integrated into society (Strachan, 2018). 


\section{4 \\ Jaafar Naser Abdulridha, Qusay Ali Abbas y Salwan jaber hashim \\ The philosophy of private deterrence in the penal code}

The Iraqi legislator states that (First: every inmate and applicant) has the right to education and further education and to all stages during the period of his sentence.

Second: The Iraqi Reform and Juvenile Reform departments must secure the need for inmates and applicants to education and continue studying by opening public or vocational schools in both departments or ensuring continued study outside of it within the scope of the requirements of internal security and the capabilities of these two departments.

Third: The Ministry of Education, in coordination with the Ministry of Justice, meets the objective requirements for implementing the programs of the Iraqi Reform and Juvenile Reform departments to educate and qualify inmates and applicants to open public and vocational schools in all their phases within the correctional departments in these two departments.

We believe that all correctional institutions should pay attention to the education of the convicts, for education, whether education related to scholastic, religious or moral, plays a very big role in reforming these prisoners, and then turning them into good individuals and removing criminal risk from the reservoirs of themselves, and this is what private deterrence seeks to achieve.

Health care for the convict: Health care is defined as a humanitarian action that restores the convict's confidence in himself and in society through the means of this care, which is to prevent diseases before they happen and to treat them after they happen. The convict and his rehabilitation instead of retaliation and terrorizing society through him, until the treatment became a right for the convict and a duty of the administration to do (AlQahwaji, 1985).

It contributes to refining the behavior of the prisoner, so that she is used to good health rules such as physical hygiene, cleaning clothes, taking care of appearance and self-esteem, which creates a different feeling for him than he was before entering prison, and makes him look at his past as inappropriate and tends to change his behavior for the better, as well as health care role Important in the rehabilitation process through the physical and psychological treatment it provides to the convict, and its protection from various diseases that may be transmitted outside the penal institution, which means the importance of care for the whole community, not only the convict, in addition to that health care has a major role in evaluating the convict.

Through the feeling it instills in the convict that he is a healthy person and it is not appropriate for him to commit crimes or return to him, in addition to the importance of this care in erasing the negative effects that the convicted person suffers from and suffers from as a result of the deprivation of liberty measures such as arrest, seizure, investigation, trial 
and what may result As a result of this negative thinking as a result of his new position among the walls of the institution.

The Iraqi legislator states that First: The Ministry of Health should cooperate with the Iraqi Reform and Juvenile Reform departments to do the following (Khidr AL-Jourani and Nooran, 2007):

A. Providing health, preventive and curative services to the inmate, the depositor, and the arrested

B. Establishing a hospital, health centers, or medical clinic in the central prisons, according to the absorptive capacity, to supervise the physical, mental and psychological health of inmates and provide health, preventive and curative services to them, provided that an appropriate number of doctors and health professionals are assigned to work.

C.Allocating a special ward for the inmate, the depositor, and the arrested in public hospitals if his health condition requires it (Lynn, 2001).

\section{Discussion}

We believe that attention to health care plays a major role in achieving the function and goals of private deterrence. Attention to health care for the convicted person leads to the elimination of diseases that may be the cause of the crime, and health care leads to attention to personal hygiene which enhances the confidence of the convict himself.

Allowing the convict to do voluntary work The voluntary action can be counted by the convicts as a clear expression of a new awareness of the reality of the matter or the situation in which the inmate found himself, and this is very important in itself, as this new awareness of the reality of the matter or the true position of the convict is considered the beginning Or a strong indication of a correct understanding and awareness on the part of the convict for the crime or delinquency he committed for the reason for his presence in the penal institutions, a realization of the community's right to react to criminal and deviant actions, but more than that, a realization of the truth of the relationship between the convict and the community, which is thus an implicit acceptance of the interaction Between the correctional institution and society on the one hand, and the convict on the other (Ahsan Mubarak, 2000).

The reform work guarantees the rehabilitation of the convict in many ways, including that it provides him with the opportunity to train for a 
specific craft in a period of time that helps him to master it, enabling him to rely on it after his release, and what he returns from it as a result of the financial reward, in addition to that he is prevented On the one condemned to break down, and the physical and psychological imbalance and turmoil that follows, in addition to the fact that he instills in himself the truth about his love of work and his usefulness in a decent life, and what leads him to raise his morale and his ability to produce.

As a result of the importance of voluntary work in correctional institutions, the legislator stipulated this type of work, as it stipulates that ((the Iraqi reform and juvenile reform departments guarantee each inmate and a 15-year-old applicant who has completed the age of fifteen years of age the right to work within the limits of his ability and qualifications within the scope of the rules Technical classification for the purpose of qualifying and training him professionally and preparing the reasons for living for him after the expiration of his sentence and helping him to integrate into society (Jones, 2000).

It also states that (it is prohibited to employ inmates and depositors with forced labor in the correctional sections) It also states that the work is part of the constituents of the correctional and rehabilitation process and not a penalty in itself and on the committees formed in the Iraqi Correctional and Juvenile Correction departments taking into account the desire of the inmate and the depositor to choose It is compatible with his capabilities and qualifications (Dobkin, 2005).

It is clear from the foregoing that working within the correctional institution is voluntary and not coercive, and as long as the work is voluntary, this indicates the desire of the convict to get rid of the criminal sediments inherent in himself, and his willingness to integrate into society and reform and cultivate himself, and then the voluntary work inside the correctional institution achieves Targets of private deterrence.

There is no doubt that private deterrence is affected by the type of punishment, as a result of the development and the emergence of new penalties stipulated in some penal laws, has led to the influence of deterrence for this punishment.

Electronic Monitoring Electronic surveillance is known as (obligating the convicted or a remand in custody to reside in his home or residence during specific hours so that the person subject to the surveillance is monitored electronically) (Saous and Sadani, 2017).

Electronic monitoring achieves all the goals of thinking, reform and benefits related to the punishment, and it represents an appropriate answer to reduce the scientific and humanitarian problems that hinder the application of traditional penalties in the closed environment, as this penalty relies on alleviating the crisis of prison overcrowding and overcrowding, 
reducing its enormous expenses, and preventing effects The negativity of the prison, by avoiding the mixing of the convict with the middle of the corrupt prison, and avoiding the negative psychological effects of the closed prison life on the other hand.

\section{Conclusions}

We note that the electronic monitoring penalty is compatible with the function of private deterrence, as the goals that the legislator aspires to achieve in private deterrence are achieved in light of the electronic monitoring penalty, and we call on the Iraqi legislator to take this punishment due to the great benefits and benefits that this punishment achieves.

The Barol Commitment System This system is known as the release of the convict after spending a certain period in prison, provided that it is placed under supervision and subject to special restrictions and directives. This system requires advance preparation for release and the inmate is subject to the penal institution, and this preparation is an important element in the program that The inmate shall be placed in the penal institution, as well as in the classification process, the type of work that he will do, the special training that is required to be obtained, and the psychological preparation of who will be released, where psychologists and social researchers have an important role in this field (Saous and Sadani, 2017).

Conditional release means conditional release is the permissibility of releasing a convict with a sentence that deprives of liberty, if he spent the greater part of this punishment in prison and proved that he deserves to be exempted from the implementation of the rest of it, after having benefited from the implementation of the greater part of it, and because of that he gave up Committing the crime, so he kept his life and good behavior) (Khidr Al-Jourani, 2007).

And the Iraqi legislator did well when he allowed the courts to issue a ruling for the conditional release of the convicted person according to the legal frameworks and limits set for them, as the conditional release system fulfills the special deterrent function as well as the general deterrent function.

The purpose of the punishment is not only repugnance and deterrence of the offender, but also aims to rehabilitate and fix the offender through the punishment imposed on him or through subsequent care. Simply enjoining and executing the corporal punishment does not lead alone to eliminating criminal risk. 
Jaafar Naser Abdulridha, Qusay Ali Abbas y Salwan jaber hashim
The philosophy of private detence

Aftercare is defined as an educational, social, economic and civilizational process aimed at the vocational, social and economic rehabilitation of the released prisoners so that they can live and practice a new life in which the previous environmental, social and economic conditions that pushed them to commit the criminal act) are overridden (Sufouh Al-Akhras, 1997).

The Iraqi legislator defined the aftercare as ((it is the care of the depositor or the inmate after the end of his rule to ensure his integration into society and not return to delinquency, and is considered a complementary measure to qualify the penal institution and the practical way to guide, guide and assist the released person to meet his needs and help him to settle in his life, integration and adaptation With his community, upon the return of the convict to the external community that he was absent from as a result of the time spent in prison, the humanitarian and social care of the released persons has great importance in the success and continuity of social rehabilitation, and the achievement of the goals of modern punitive policy, in order to ensure the protection of society from the risks of the return of the criminal To crime again) (Sufouh Al-Akhras, 1997).

Jurisprudence differed in determining what is meant by private deterrence, as there is security in the determination of what is meant by deterrence, although most doctrinal definitions revolve around that deterrence is the eradication of criminal risk from the same convict and his reform, rehabilitation and rehabilitation.

The philosophical basis for private deterrence is disputed between two schools, the positivist school whose policy was to protect society from the dangerous character of the offender, by reforming and correcting it, and the school of social defense which holds that fighting crime is one of the most important duties of society.

Private deterrence has multiple goals, including what is on the social level, as reforming the perpetrator leads to reassuring society that the perpetrator did not commit the same crime that he committed, but on the personal level, it is reform, refinement and rehabilitation of the perpetrator himself.

One of the most important manifestations of private deterrence when carrying out the punishment is through the education and refinement of the convict, as well as through caring for his health care, as well as through the participation of the convict in voluntary work.

Deterrence is affected by the type of sanctions, and the sanctions developed are more important and achieve the goals of private deterrence more like the electronic monitoring of the convicts and the system of pledging honorable parole. 
Aftercare for convicts plays a major role in reforming convicts through the functions it performs in reforming, refining and rehabilitating perpetrators.

We suggest that the Iraqi legislator introduce some of the newly introduced penalties, such as the voluntary work system inside the prison or electronic monitoring, given that these penalties bring great benefits to the reform and refinement of the convicts.

We call on the Iraqi legislator to pay attention to the convicts by teaching and polishing him inside the penal institution (prison - imprisonment) and paying attention to his health care, as well as allowing him to work inside the penal institution according to fair and just conditions.

We call on the Iraqi legislator to replace some of the penalties stipulated in the Iraqi Penal Code No. 111 of 1969, as amended, especially penalties of imprisonment for a short period, and replace them with other penalties. We call on the Iraqi legislator to pay more attention to the issue of aftercare for the convicts, by providing job opportunities and giving them material assistance that helps them To integrate in a faster way in society. We recommend the Iraqi legislator to deal firmly and severely, by denying those convicted of some serious crimes, especially terrorist crimes, all the rights and privileges that are granted to the convicts while serving their sentence within the penal institution.

\section{Thanks}

The work is performed according to the Russian Government Program of Competitive Growth of Kazan Federal University.

\section{Bibliographic References}

AHSAN MUBARAK, T. 2000. Voluntary Work for Inmates of Reform Institutions. First Edition. Naif Arab Academy for Security Sciences. Riyadh, Saudi Arabia.

AL-QAHWAJI, A.Q. 1985. Criminology and Punishment. University House. Beirut, Lebanon.

AL-TAHER, B. 2009. The Philosophy of the Punitive System in Algeria and the Rights of the Prisoner. Dar Al-Hoda for Printing, Publishing and Distribution. Beirut, Lebanon. 
Jaafar Naser Abdulridha, Qusay Ali Abbas y Salwan jaber hashim

JONES, Jason. 2000. "Prisoner Litigation and the Mistake of Jenkins v. Haubert” In: Cornell Law Review. Vol. 86, No. 10, pp. 34-65.

KHIDR AL-JOURANI, N. 2007. Theory of Repentance in Criminal Law. PhD thesis. University of Babylon. Babylon, Iraq.

LYNN, Branham. 2001. "The Prison Litigation Reform Act's Enigmatic Exhaustion Requirement: What It Means and What Congress, Courts and Correctional Officials Can Learn from It" In: Cornell Law Review. Vol. 86, No. 93, p. 483.

MEKKI, D. 2010. The Abstract in the Science of Punishment. 2nd edition. University Press Office. Algeria, Algiers.

SAOUS, Kheira A; SADANI, Nora Yahia. 2017. "Criminal Penalties Against Environmental Pollution According to The Provision of the Algerian Legislation" In: Journal of Juridical and Political Science. Vol. 6, No. 2, pp. 95-117.

STRACHAN, Anna. 2018. "The Criminal Justice System and Stability in Algeria. K4D Helpdesk Report. Brighton, UK" In: Institute of Development Studies. Available online. In: https://opendocs.ids.ac.uk/opendocs/ handle/20.500.12413/13877. Fecha de consulta: 12/03/2019.

SUFOUH AL-AKHRAS, M. 1997. Rehabilitation programs and the realization of aftercare for the released. Arab Center for Security Studies and Training. Riyadh, Saudi Arabia. 
Vol.38 NEspecial

Esta revista fue editada en formato digital y publicada en diciembre de 2020, por el Fondo Editorial Serbiluz, Universidad del Zulia. Maracaibo-Venezuela 